\title{
Pengaruh Citra Merek, Desain Produk Dan Kualitas Produk Terhadap Keputusan Pembelian Sepatu Merek Bata
}

\author{
Dewi Saidatul Mukarromah, Chusnul Rofiah \\ STIE PGRI Dewantara Jombang \\ Korespondensi: chusnulrofiah@yahoo.com
}

\begin{abstract}
Abstrak
Penelitian ini bertujuan penelitian ini untuk mengetahui pengaruh variabel citra merek, desain produk dan kualitas produk terhadap keputusan pembelian sepatu Bata di Ruko Citra Niaga Jombang. Populasi pada peneitian ini konsumen sepatu Bata yang membeli di outlet sepatu Bata di Ruko Citra Niaga Jombang, sedangkan sampel yang digunakan dalam penelitian ini berjumlah 100 responden dengan menggunakan teknik Non Probability Sampling. Instrument penelitian ini menggunakan angket dan dianalisis menggunakan analisis regresi berganda, uji hipotesis dan uji asumsi klasik dengan SPSS for windows versi 20. Berdasarkan hasil penelitian ini menunjukkan bahwa peningkatan keputusan pembelian dapat disebabkan oleh: 1) Citra merek yang baik, meliputi kenyamanan saat dipakai, kesan yang mewah, model yang beragam dan warna yang bervariasi; 2) Desain produk meliputi desain mewah, kuat dan awet serta pilihan yang sangat bervariasi dan 3) Kualitas produk meliputi fitur dan rancangan produk.
\end{abstract}

Kata kunci : Citra merek, Desain Produk, Kualitas Produk, Keputusan Pembelian

\section{Abstract}

This study aims to determine the effect of variable brand image, product design and product quality on the decision to purchase Bata shoes in Ruko Citra Niaga Jombang. The population in this research was Bata shoe consumers who bought at Bata shoe outlets in Ruko Citra Niaga Jombang, while the samples used in this study were 100 respondents using the Non Probability Sampling technique. This research instrument uses questionnaires and analyzed using multiple regression analysis, hypothesis testing and classic assumption test with SPSS for Windows version 20. Based on the results of this study indicate that an increase in purchasing decisions can be caused by: 1) Good brand image, including comfort when used, luxurious impression, diverse models and varied colors; 2) Product design includes luxurious design, strong and durable as well as very varied choices and 3) Product quality includes product features and design. Keywords: Brand Image, Product Design, Product Quality, Purchasing Decision

\section{A. PENDAHULUAN}

Perkembangan dunia usaha dewasa ini telah diwarnai oleh persaingan yang semakin ketat. Hal ini diakibatkan karena adanya arus globalisasi yang semakin terbuka lebar bagi setiap pelaku bisnis. Timbulnya persaingan yang sangat ketat tersebut menyebabkan kalangan usaha saling berlomba untuk dapat menghadapi persaingan dan mendapatkan keunggulan kompetitif. Persaingan mencakup semua penawaran dan produk yang ditawarkan oleh pesaing, baik yang aktual maupun yang potensial, yang mungkin dipertimbangkan oleh seorang pembeli (Kotler (2012).

Banyak produsen barang dan jasa dari suatu negara bersaing dengan produsen dari negara lain untuk menarik minat konsumen dalam perdagangan nasional maupun internasional. Untuk mempertahankan persepsi yang positif di benak konsumen, perusahaan harus melakukan strategi pemasaran yang tepat untuk meraih pangsa pasar serta membangun image merk agar melekat di benak masyarakat (Wirayanthy, N., \& Santoso, S, 2018). Dengan banyaknya para pesaing baru dan semakin pesatnya perkembangan teknologi menyebabkan perusahaan harus selalu mengetahui kebutuhan ruko pada saat ini. Pentingnya memahami kemauan konsumen dalam produk yang 
diinginkan telah menjadi perhatian pada sekian banyak industri. Salah satunya ialah industri sepatu, sebab perkembangan industri sepatu sangat pesat seiring dengan peningkatan permintaan akan sepatu dengan kualitas dan model yang lebih modern.

Rumusan masalah yang diangkat pada penelitian ini adalah: 1) Apakah variabel citra merek berpengaruh signifikan terhadap keputusan pembelian sepatu Bata?, 2)Apakah variabel desain produk berpengaruh signifikan terhadap keputusan pembelian sepatu Bata? Dan 3) Apakah variabel kualitas produk berpengaruh signifikan terhadap keputusan pembelian sepatu Bata? Hasil dari penelitian ini diharapkan bermanfaat khususnya bagi pihak manajemen produsen sepatu Bata agar mampu terus bersaing dan menjadi pilihan bagi konsumen sepatu.

\section{B. KAJIAN PUSTAKA}

\section{Citra Merek}

Menurut Setiadi (2003) citra merek berhubungan dengan sikap yang berupa keyakinan dan preferensi suatu merek. Konsumen yang memiliki citra positif terhadap suatu merek akan lebih memungkinkan untuk melakukan pembelian. Menurut Kotler dan (Armstrong (2001) citra merek ialah anggapan dari konsumen terhadap produk dari suatu perusahaan. Menurutnya, citra suatu merek bisa selalu diingat didalam pikiran pelanggan dalam waktu yang cepat dan melalui suatu media, citra suatu merek harus juga disampaikan kepada pelanggan lewat sarana komunikasi yang tersedia dan disebarkan secara berkelanjutan karena tanpa merek yang kuat maka sangatlah susah bagi sebuah perusahaan untuk mampu menarik pelanggan baru untuk membeli produk dari perusahaan tersebut dan menciptakan loyalitas dari konsumen yang telah ada.

\section{Desain Produk dan Kualitas Produk}

Kotler (2011) menyatakan desain ialah totalitas kesempurnaan yang mempengaruhi rasa, bentuk dan manfaat produk berdasarkan keperluan pelanggan. barang yang tahan lama dan berkualitas merupakan faktor penting dalam pembuatan desain. Perusahaan seharusnya bisa menciptakan produk yang memiliki kelebihan dari para kompetitor sehingga dapat menjadi pilihan utama dimata konsumen dibanding dengan produk dari kompetitor lain. Diantaranya dengan desain produk. Sedangkan menurut Kotler dan Armstrong (2001) desain produk ialah proses mendesain bentuk dan manfaat dari produk tersebut sehingga bisa memiliki suatu ciri-ciri yang khas. desain secara sederhana menggambarkan bentuk luar produk. Wujud produk yang menarik ialah gambaran dari desain yang berkualitas. Perancang yang baik memperhitungkan bentuk luar dari produk dan juga menghasilkan produk yang aman, murah, dan gampang untuk setiap pemakaian, serta ekonomis untuk diproduksi serta pendistribusiannya Kotler dan Armstrong (2001).

Sedangkan kualitas produk menurut Kotler dan Amstrong (2008) ialah bagaimana produk tersebut memiliki manfaat yang bisa menyenangkan konsumen baik melalui bentuk fisik maupun secara pikiran yang menunjuk pada kelengkapan atau ciri-ciri yang ada dalam suatu barang. Assauri (2004) menerangkan bahwa kualitas produk ialah hal yang ada pada suatu barang atau hasil yang mengakibatkan barang tersebut sesuai dengan tujuan yang dimaksudkan. Kualitas produk ialah faktor penting yang semestinya harus dilaksanakan oleh setiap perusahaan bilamana ingin menggarapkan produk yang diciptakan bisa bersaing dengan pesaingnya. Dikarenakan tingkat pendidikan dan perekonomian masyarakat lebih meningkat, sebagaian masyarakat semakin bijak dalam memilih sebuah produk. Konsumen menginginkan produk yang 
berkualias sesuai dengan nilai yang dibayarkan, meskipun ada sebagian masyarakat yang beranggapan bahwa, produk yang mahal adalah yang berkualitas.

\section{Keputusan Pembelian}

Schiffman dan Kanuk (2014) menyatakan keputusan pembelian ialah sebuah tindakan dari beberapa atau lebih alternatif yang ada. Untuk melakukan proses keputusan pembelian pada dasarnya memerlukan ketepatan dan ketelitian dalam memutuskan untuk melakukan suatu pembelian produk atau jasa yang dapat diharapkan oleh konsumen. Perilaku pembelian konsumen bisa merujuk pada perilaku membeli konsumen akhir yaitu individu atau rumah tangga yang membeli suatu barang dan jasa untuk dikonsumsi pribadi

Konsumen di dunia sangat berbeda dalam urusan tingkat pendidikan, pendapatan ,dan selera mereka dalam membeli macam macam jenis barang dan jasa. Bagaimana konsumen yang begitu berbeda ini memutuskan pilihan diantara sekian banyak produk yang beredar merupakan suatu susunan faktor yang menarik.

Berdasarkan latar belakang dan kajian pustaka yang telah disampiakan maka rumusan hipotesis pada penelitian ini adalah:

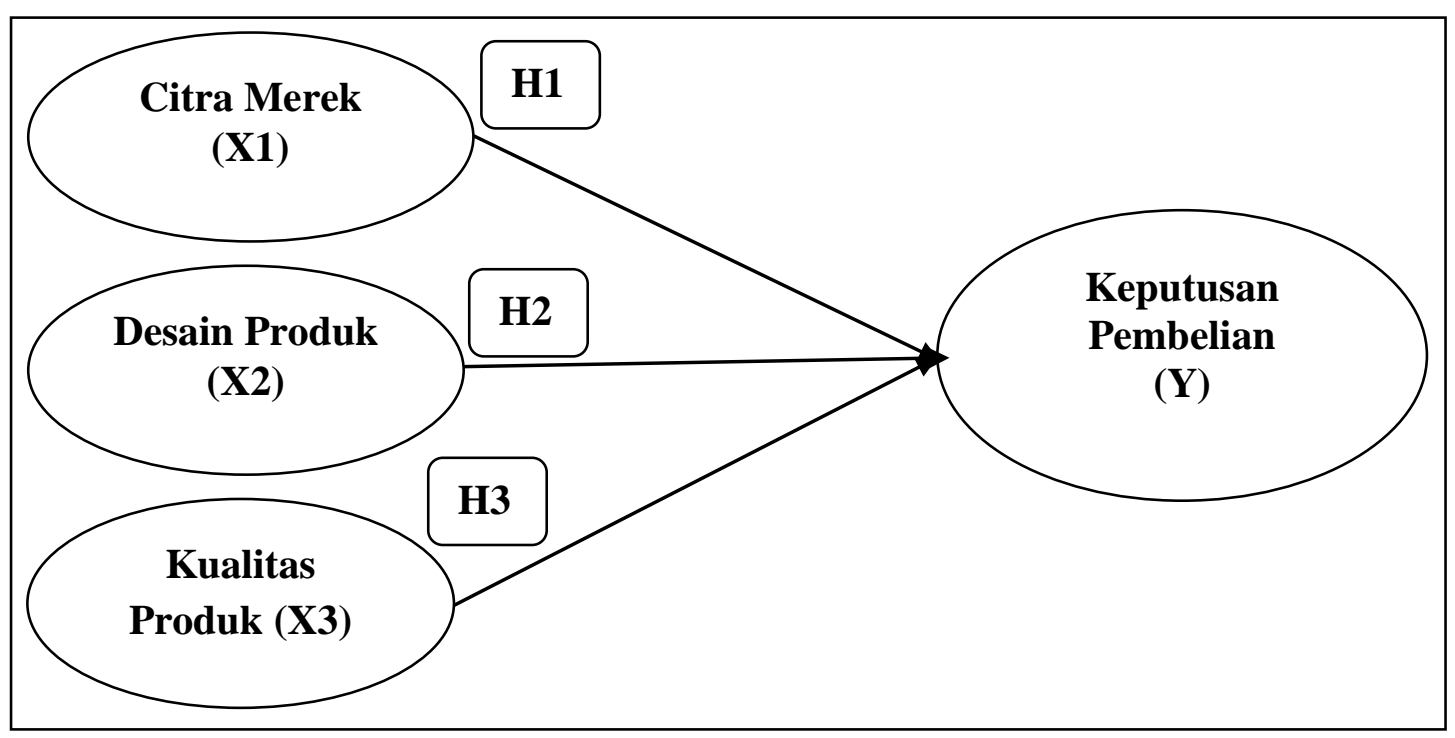

\section{Hipotesis:}

\section{Gambar 1: Rumusan Hipotesis}

H1: Diduga, Citra Merk berpengaruh pada Keputusan Pembelian

H2: Diduga, Desain Produk berpengaruh pada Keputusan Pembelian

H3: Diduga, Kualitas Produk berpengaruh pada Keputusan Pembelian

\section{METODE PENELITIAN}

Tujuan dari penelitian ini yaitu untuk mengetahui sejauh mana pengaruh Citra merek desain Produk dan kualitas produk terhadap keputusan pembelian produk Sepatu Bata pada Toko Sepatu BATA Ruko Citra Niaga Jombang. Variabel bebas (independent variable) pada penelitian ini yaitu Citra Merk (X1), Desain Produk (X2) dan Kualitas produk (X3), sedangkan yang menjadi variabel terikat (Y) atau dependent variable atau adalah keputusan pembelian Sepatu Bata pada Toko Sepatu BATA Ruko Citra Niaga Jombang. Penelitian ini menggunakan rancangan penelitian Analisis deskriptif, dimana penelitian ini dilakukan untuk mengetahui pengaruh antar variabel 
yang akan diteliti dalam obyek atau subyek yang akan diteliti tanpa menghubungkan dengan variabel yang lain. Alat Uji menggunakan Analisa Regresi Linear Berganda dan untuk menguji hipotesis yang diajukan menggunakan $\mathrm{Uji}-\mathrm{T}$.

Uji validitas bisa diketahui dengan melihat $r$ hitung, apabila $r$ hitung sig. $\leq 0,05=$ valid dan $r$ hitung sig. $>0,05=$ tidak valid. Suatu variabel dikatakan relliabel apabila : Hasil $\alpha>0,60=$ reliabel dan Hasil $\alpha<0,60=$ tidak reliabel.

\section{HASIL PENELITIAN DAN PEMBAHASAN}

\section{Analisis Regresi Linier Berganda}

Analisis yang digunakan dalam penelitian ini adalah analisis regresi linier berganda. Dalam analisis regresi ini dapat digunakan untuk mengukur kekuatan hubungan antara dua variabel atau lebih, juga menunjukkan arah hubungan antar variabel dependen (Keputusan Pembelian) dengan variabel independen (Citra Merek, Desain Produk dan kualitas produk) secara parsial pada keputusan pembelian. Berdasarkan hasil perhitungan SPSS versi 20 diperoleh tabel analisis regresi linier berganda dibawah ini :

Tabel 1: Hasil Uji Regresi Linier Berganda

\begin{tabular}{|c|c|c|c|c|c|}
\hline \multicolumn{6}{|c|}{ Coefficients $^{\mathrm{a}}$} \\
\hline \multirow[t]{2}{*}{ Model } & \multicolumn{2}{|c|}{$\begin{array}{l}\text { Unstandardized } \\
\text { Coefficients }\end{array}$} & \multirow{2}{*}{$\begin{array}{c}\begin{array}{c}\text { Standardized } \\
\text { Coefficients }\end{array} \\
\text { Beta }\end{array}$} & \multirow[t]{2}{*}{$\mathrm{t}$} & \multirow[t]{2}{*}{ Sig. } \\
\hline & B & Std. Error & & & \\
\hline (Constant) & 5,471 & 2,110 & & 2,592 & ,011 \\
\hline $\mathrm{X} 1$ & 295 & ,090 & ,301 & 3,291 & ,001 \\
\hline $\mathrm{X} 2$ & , 164 &, 080 & ,213 & 2,056 & ,043 \\
\hline $\mathrm{X} 3$ & ,314 &, 126 & ,252 & 2,484 & ,015 \\
\hline
\end{tabular}

a. Dependent Variable: Y

Sumber: Data Primer Diolah, 2018

Dari tabel diatas maka persamaan regresi yang terbentuk adalah sebagai berikut :

$$
\hat{Y}=5,471+0,295 X 1+0,164 X 2+0,314 X 2
$$

Dari persamaan diatas tampak bahwa nilai signifikansi dari seluruh variabel adalah < 0,05 sehingga bisa disimpulkan bahwa variabel citra merek (X1), desain produk (X2), dan kualitas produk (X3) konstan, berpengaruh pada keputusan pembelian (Y)

\section{Uji Asumsi Klasik}

Uji Normalitas bertujuan untuk mengetahui sebuah data mengikuti atau mendekati distribusi normal. Uji normalitas dilakukan dengan menggunakan pendekatan grafik dan pendekatan Kolmogorov Smirnov. Dari hasil pendekatan grafik, diketahui bahwa titik-titik terletak di sepanjang garis diagonal yang berarti berarti data berdistribusi normal, sebagaimana yang tampak pada gambar berikut: 


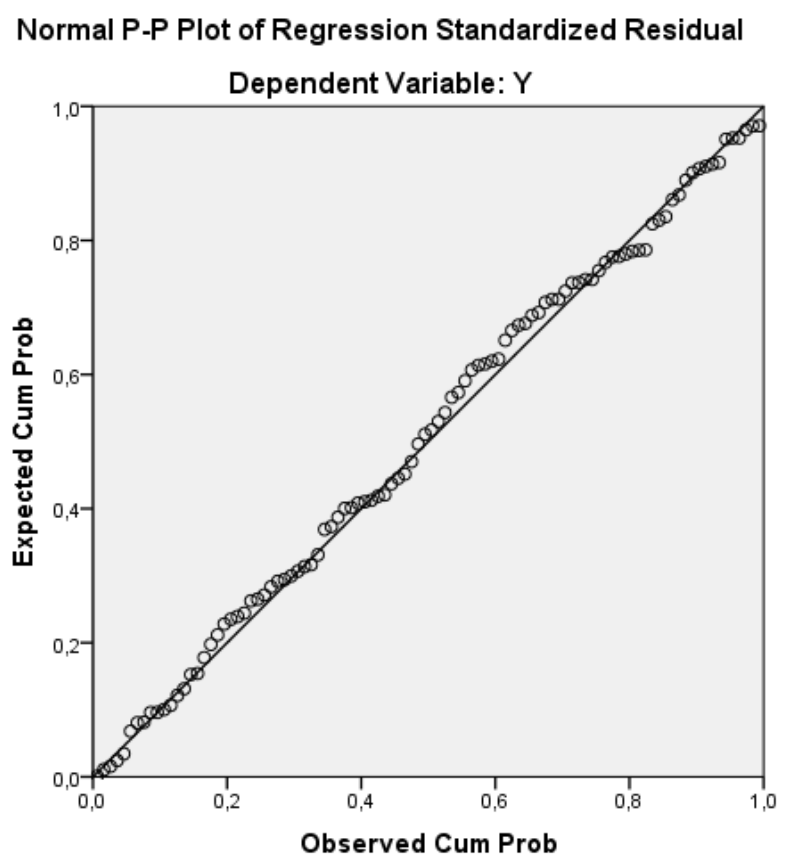

Gambar 2: Hasil Output Normalitas

Untuk mengetahui adanya linier yang sempurna dilakukan Uji Multikoliniertas. Deteksi terhadap adanya multikolinieritas adalah dengan melihat besaran Variance Inflation Factor (VIF) dan Tolerance melalui SPSS dan koefesien korelasi antar variabel bebas. Antar variabel tidak terjadi multikolinieritas jika VIF $<10$ dantolerance diatas 0,1. Dari hasil pengolahan data, tampak pada tabel berikut:

Tabel 2: Uji Multikolinieritas

\begin{tabular}{|c|c|c|c|c|c|c|c|}
\hline \multicolumn{8}{|c|}{ Coefficients $^{\mathbf{a}}$} \\
\hline \multirow[t]{2}{*}{ Model } & \multicolumn{2}{|c|}{$\begin{array}{c}\text { Unstandardized } \\
\text { Coefficients }\end{array}$} & \multirow{2}{*}{$\begin{array}{c}\begin{array}{c}\text { Standardized } \\
\text { Coefficients }\end{array} \\
\text { Beta }\end{array}$} & \multirow[t]{2}{*}{$\mathrm{T}$} & \multirow[t]{2}{*}{ Sig. } & \multicolumn{2}{|c|}{ Collinearity Statistics } \\
\hline & $\mathrm{B}$ & Std. Error & & & & Tolerance & VIF \\
\hline (Constant) & 5,471 & 2,110 & & 2,592 & ,011 & & \\
\hline$\underline{X 1}$ & ,295 & (090 & ,301 & 3,291 & , no1 & ,768 & 1,301 \\
\hline $\mathrm{X} 2$ & ,164 &, 080 & ,213 & 2,056 &, 043 & ,598 & 1,672 \\
\hline $\mathrm{X} 3$ & ,314 & , 126 & ,252 & 2,484 &, 015 & ,627 & 1,595 \\
\hline
\end{tabular}

a. Dependent Variable: Y

Sumber: Data Primer diolah, 2018

Berdasarkan tabel 2 diatas diperoleh nilai VIF dari semua variabel lebih kecil dari 10 dan nilai tolerance semua variabel lebih besar dari 0,1. Dengan demikian kedua variabel bebas tersebut tidak terjadi multikolinieritas

\section{Uji Autokorelasi}

Uji ini bertujuan untuk menguji apakah dalam model regresi linier ada korelasi antara kesalahan pengganggu pada periode $t$ dengan kesalahan pengganggu pada periode t-1 (sebelumnya). Untuk mengetahui ada tidaknya autokorelasi dapat dilakukan dengan uji Durbin Watson test. Kemudian nilai d hitung akan dibandingkan dengan 
nilai $\mathrm{d}_{\text {tabel }}$ dengan tingkat signifikan 5\% $(0,05)$. Jika DW hitung berada diantara dU (batas atas) dan dL (batas bawah) maka tidak ada autokorelasi. Dari hasil pengolahan data, tampak hasilnya sebagai berikut:

Tabel 3: Uji Autokorelasi

\begin{tabular}{|c|c|c|c|c|c|}
\hline \multicolumn{6}{|c|}{ Model Summary $^{\mathbf{b}}$} \\
\hline$\overline{\text { Model }}$ & $\mathrm{R}$ & R Square & $\begin{array}{c}\text { Adjusted R } \\
\text { Square }\end{array}$ & $\begin{array}{l}\text { Std. Error of } \\
\text { the Estimate }\end{array}$ & Durbin-Watson \\
\hline 1 &, $618^{\mathrm{a}}$ & ,382 & ,363 & 2,400 & 1,743 \\
\hline
\end{tabular}

Dari hasil pengujian diperoleh nilai DW (d) sebesar 1,743. Sedangkan nilai du menurut tabel untuk sampel (n) 100 dengan variabel independen $3(\mathrm{k}=3)$ adalah 1,736, sehingga didapat nilai $\mathrm{du}<\mathrm{d}<4-\mathrm{du}$. $(1,736<1,743<2-1736)$. Nilai ini merupakan syarat tidak terjadinya autokorelasi.

\section{Uji Heteroskedastisitas}

Uji ini bertujuan untuk mengetahui apakah terjadi ketidaksamaan varians dari residual suatu pengamatan ke pengamatan lain. Model yang bebas dari heteroskedastisitas memiliki grafik Scatter plot dengan pola titik yang menyebar diatas dan dibawah sumbu Y. Hasil dari pengolahan data, tampak seperti gambar berikut:

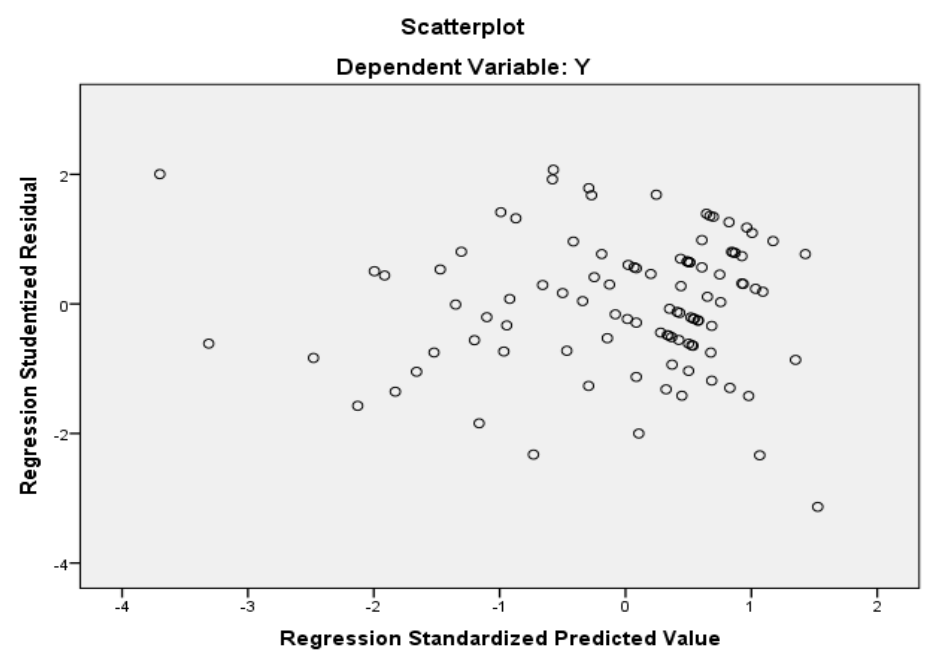

Gambar 4 Grafik Scatter plot

Berdasarkan gambar 4 diatas dapat dilihat bahwa grafik Scatter Plot terlihat titik-titik yang menyebar secara acak baik diatas maupun dibawah angka 0 pada sumbu Y. Jadi dapat disimpulkan bahwa tidak terjadi heteroskedastisitas pada model regresi ini.

\section{Uji Hipotesis}

Untuk menguji hipotesis yang telah diajukan selanjutnya dilakukan Uji parsial (T-Test) . Hal ini dilakukan guna menguji signifikansi pengaruh variabel-variabel independen yang meliputi citra merek, desain produk dan kualitas produk terhadap variabel dependen yaitu keputusan pembelian. Dalam penelitian ini digunakan toleransi 
kesalahan atau level of significant $(\alpha)$ sebesar $5 \%$ atau $\alpha=0.05$ (df) sebesar $\mathrm{n}-\mathrm{k}-1=$ $100-4-1=95$, sehingga diperoleh $t_{\text {tabel }}$ sebesar 1.985 . Hasil uji $t$ variabel independent $(\mathrm{X})$ terhadap variabel dependent $(\mathrm{Y})$ dapat dilihat pada tabel 1 diatas dan dapat disimpulkan bahwa dari ketigas variabel bebas tersebut berpengaruh signifikan terhadap keputusan pembelian adalah variabel citra merek, desain produk dan kualitas produk. Sehingga disimpulkan bahwa seluruh hipotesis yang diajuka terbukti bisa diterima.

Untuk mengetahui seberapa besar varian dari variabel dependen dapat dijelaskan oleh variabel independen digunakan Uji Koefisien determinasi. Berdasarkan tabel 1 (satu) diatas diperoleh nilai $\mathrm{R}^{2}$ sebesar 0,382, yang dapat disimpulkan bahwa $38,2 \%$ variasi perubahan keputusan pembelian dijelaskan oleh perubahan faktor citra merek desain produk, dan kualitas produk sementara sisanya 61,8\% dijelaskan oleh faktor lain yaitu seperti variabel harga, promosi iklan, kualitas pelayanan, gaya hidup dan variabel produk yang tidak diteliti dalam penelitian ini.

Dari hasil analisis didapat bahwasanya variabel citra merek berpengaruh secara langsung atau signifikan terhadap keputusan pembelian sepatu bata di Toko Bata Jombang, kenyamanan saat dipakai, kesan yang mewah, model yang beragam dan warna yang bervariasi membuat pelanggan tertarik untuk membeli sepatu Bata.Citra merek berperan dalam mempengaruhi suatu keputusan pembelian. Citra merek merupakan persepsi baik atau buruk dari komnsumen terhadap suatu merek. Merek yang memiliki citra baik dapat meningkatkan keputusan pembelian pada suatu produk. Menurut (Ekawati (2014) konsumen cenderung melakukan pembelian pada merek yang sudah dikenal, karena merasa aman dengan sesuatu yang dikenal dan memiliki anggapan bahwa merek tersebut memiliki kualitas yang dapat dipertangung jawabkan dan diandalkan.

Citra mempunyai pengaruh penting pada manajemen. Citra yang negatif dan tidak jelas akan berpengaruh negatif terhadap kinerja karyawan dan hubungan dengan konsumen. Sebaliknya citra positif dan jelas, misalnya citra organisasi dengan pengalaman yang sangat baik secara internal menceritakan nilai-nilai yang jelas dan menguatkan sikap positif terhadap organisasi. Menurut (Sutisna (2001) citra yang baik dari suatu organisasi akan mempunyai dampak yang menguntungkan, sedangkan citra yang jelek akan merugikan organisasi. Citra yang baik berarti masyarakat (khususnya konsumen) mempunyai kesan positif terhadap suatu organisasi, sehingga citra yang kurang baik berarti masyarakat mempunyai kesan yang negatif).

\section{Pengaruh desain produk terhadap keputusan pembelian}

Desain produk, terbukti secara signifikan berpengaruh kepada keputusan pembelian. Desain sepatu Bata yang cocok digunakan sehari-hari, terlihat mewah, kuat dan awet serta pilihan yang sangat bervariasi membuat pelanggan tertarik untuk membeli sepatu Bata. Faktor kedua yang mempengaruhi keputusan pembelian adalah desian produk. Menurut Kotler (2005) mengartikan "Desain atau rancangan adalah totalitas keistimewaan yang mempengaruhi penampilan fungsi produk dari segi kebutuhan pelanggan”. Bagi perusahaan, produk yang didesain dengan baik adalah produk yang mudah diproduksi dan didistribusikan. Sedangkan bagi pelanggan, produk yang didesain dengan baik adalah produk yang menyenangkan untuk dilihat dan mudah dibuka, dipasang digunakan, diperbaiki serta dibuang.

Kotler dan Keller (2012) mengatakan bahwa desain yang baik bagi perusahan merujuk pada kemudahan dalam pembuatan dan distribusi. Sedangkan bagi konsumen, desain yang baik adalah produk yang indah atau bagus untuk dilihat, mudah di buka, 
dipasang, digunakan, diperbaiki, dan dibuang. Desain produk adalah fitur yang terdapat dalam suatu produk yang membedakan produk tersebut dari produk pesaing. Oleh sebab itu, produk yang dihasilkannya tidak hanya terfokus pada tampak luarnya saja namun kenyamanan saat memakai produk dan kualitas produknya juga selalu diperhatikan.

Hasil penelitian ini relevan dengan penelitian sebelumnya yang dilakukan oleh (Fuad Asshiddieqi (2012) melakukan penelitian yang berjudul "Analisis Pengaruh Harga, Desain Produk dan Citra Merek terhadap Keputusan Pembelian". Hasil penelitian menunjukkan bahwa desain produk terbukti mempengaruhi keputusan pembelian konsumen yang membeli produk Crooz di Distro Ultraa store Semarang.

\section{Pengaruh kualitas produk terhadap keputusan pembelian}

Kualitas produk juga terbukti secara signifikan berpengaruh terhadap keputusan pembelian sepatu bata di Toko Bata Jombang. Kualitas sepatu bata yang unggul dibanding produk lain, fitur dan rancangan produk yang bagus membuat pelanggan tertarik untuk membeli sepatu bata. Sumarwan (2004) menyatakan pada hakikatnya seseorang membeli barang atau jasa untuk memuaskan kebutuhan atau keinginan. Seseorang membeli barang bukan hanya fisik semata, melainkan manfaat yang ditimbulkan oleh barang atau jasa yang dibeli. Maka dari itu pengusaha dituntut untuk selalu kreatif, dinamis dan berfikiran luas. Selain itu pengetahuan konsumen mengenai produk juga akan mempengaruhi keputusan pembelian. Pengetahuan produk ini meliputi kelas produk, bentuk produk, merek dan fitur produk. Dengan demikian apabila produk yang berkualitas akan menjadi pertimbangan dalam pengambilan keputusan.

Hasil penelitian ini mendukung penelitian sebelumnya tentang kualitas produk yang telah dilakukan oleh Wiratama (2012), yang menyatakan kualitas produk berpengaruh signifikan terhadap keputusan pembelian. Hal ini menunjukkan bahwa kualitas produk berpengaruh positif dan signifikan terhadap keputusan pembelian, terbukti kebenarannya.

\section{E. PENUTUP}

Berdasarkan hasil penelitian dan pembahasan yang telah disampaikan, dapat disimpulkan bahwa Citra merek, Desain produk dan Kualita produk berkontribusi terhadap peningkatan keputusan pembelian. Semakin baik citra merek, desain yang dibuat serta kualitas sepatu Bata maka semakin tinggi pula keputusan pembelian sepatu bata.

Maka sesuai dengan simpulan tersebut diatas, disarankan kepada perusahaan untuk selalu membuat inovasi-inovasi dalam menciptakan model sepatu terbaru dan diiringi dengan kualitas yang baik maka konsumen akan memberikan kesan positif terhadap sepatu Bata. Toko sepatu Bata Jombang juga perlu memperhatikan keputusan pembelian terutama merekomendasikan kepada orang lain untuk melakukan pembelian di Toko sepatu Bata Jombang misalnya dengan menciptakan image yang baik kepada konsumen.

Sedangkan bagi peneliti selanjutnya, hendaknya perlu dilakukan pengkajian dengan cara memperdalam atau mengembangkan variabel penelitian misalnya menggunakan variabel harga dan promosi, sehingga dapat diperoleh temuan lainnya bagi pengembangan ilmu pengetahuan, misalnya kepuasan konsumen dengan loyalitas Toko sepatu Bata Jombang dengan menggunakan analisis diskriminan. 


\section{DAFTAR PUSTAKA}

Aditya Yoga Wiratama 2012, Analisis Pengaruh Produk, Persepsi Harga, Dan Citra Merek Terhadap Keputusan Pembelian Sepatu Olahraga Merek Nike Di Kota Semarang. Jurnal Skripsi, Fakultas Ekonomika Dan Bisnis Universitas Diponegoro Semarang.

Arikunto, Suharsimi, 2006, Prosedur Penelitian: Suatu Pendekatan Praktek,Edisi Revisi, PT. Rineka Cipta, Jakarta.

Arikunto, Suharsimi. (2010). Manajemen Penelitian. Jakarta: Rineka Cipta.

Assauri, S. (2010). Manajemen Pemasaran Dasar Konsep dan Strategi. Jakarta: Raja Grafindo Persada.

Assauri, Sofjan, (2004), Manajemen Produksi. Edisi Ketiga, Lembaga Penerbit Fakultas Ekonomi Universitas Indonesia, Jakarta.

Asshiddieqi, Fuad. 2012. Analisis Pengaruh Harga, Desain Produk dan Citra Merek terhadap Keputusan Pembelian (Studi Kasus pada Produk Crooz di Distro Ultraa Store Semarang). Diponegoro Journal Of Management Volume 1, Nomor 1, Tahun 2012, Halaman 1-9 http://ejournals1.undip.ac.id/index.php/dbr.

Kotler, Philip dan Amstrong Gary. (2001). Prinsip-Prinsip Pemasaran. Alih bahasa Bob Sabran M.M. Edisi Bahasa Indonesia. Jilid 1. Jakarta: Erlangga.

Kotler, Philip dan Keller, Kevin Lane. 2009. Manajemen Pemasaran. Jilid 1. Edisi ke 13. Diterjemahkan oleh: Bob Sabran. Erlangga, Jakarta.

Kotler, Philip dan Keller, Kevin Lane. 2009. Manajemen Pemasaran. Jilid 1. Edisi ke 13. Diterjemahkan oleh: Bob Sabran. Erlangga, Jakarta.

Kotler, Philip dan Keller, Kevin Lane. 2012. Marketing Management 14e Global Edition. Pearson Education Limited.

Kotler, Philip. 2005. Manajamen Pemasaran, Jilid 1 dan 2. Jakarta: PT. Indeks Kelompok Gramedia.

Kotler, Philip. 2007. Marketing Management. 11th edition. Prentice Hall, New Jersey

Kotler, Philip.2002.Manajemen Pemasaran, edisi millennium, jilid 1. PT. Prenhalindo, Jakarta.

Luthfia , W. E. (2012). Analisis Pengaruh Kualitas Produk, Kualitas Layanan, dan Harga Terhadap Keputusan Pembelian Pada Coffee Shop Kofisyop Tembalang. Skripsi pada Fakultas Ekonomi dan Bisnis Universitas Dipenogoro. Semarang

Mas Murni Distributor Oasis Cabang Jakarta Selatan). Jurnal Skripsi, Fakultas Ekonomika Dan Bisnis Universitas Diponegoro Semarang.

Mustikasari, Wening, Setiyo Budiyarti (2013). Pengaruh kualitas produk, desain produk dan harga terhadap keputusan pembelian kopiah Merk Gading Gajah Gresik. Ejournal.unesa.ac.id diakses tgl 3 Oktober 2015

Mutmainnah (2015). Pengaruh kualitas produk dan harga terhadap keputusan pembelian Rinso Cair (Studi pada ibu-ibu rumah tangga Pulo Tegalsari Wonokromo Surabaya). Ejournal.unesa.ac.id diakses tgl 3 Oktober 2015

Nuki Dian Marchiani, Wahyu Hidayat, Reni Sinta Dewi (2013). Pengaruh gaya hidup, citra merk, dan kualitas produk terhadap keputusan pembelian sepatu sneakers merk Converse. Ejournal.unesa.ac.id

Petricia, Diana (2015). Pengaruh Kualitas Produk, Harga, Promosi, dan Kualitas Pelayanan Terhadap Proses Keputusan Pembelian (Studi Kasus Konsumen Kopi Progo Bandung). Skripsi Universitas Telkom Bandung 
Robby Selestio 2013, Analisis Pengaruh Citra Merek, Kualitas Produk Dan Promosi Terhadap Keputusan Pembelian Air Minum Dalam Kemasan (Amdk) Merek Oasis (Studi Pada Konsumen Cv. Sinar

Santoso, Singgih. 2010. Statistik Multivariat: Konsep dan Aplikasi dengan SPSS. Jakarta: Elex Media Komputindo.

Schiffman, Leon G. \& Kanuk, Leslie Lazar.(2010). Consumer Behaviour: New Jersey: Pearson Education Inc.

Schiffman, Leon, Kanuk, Leslie Lazar and Wisenblit, Joseph. (2013). Consumer Behavior, 10 Edition, Prentice Hall, Singapore .

Schifman, Leon G \& Keanuk, Leslie Lazar. (2007). Perilaku Konsumen (Edisi Ketujuh). Jakarta: Indeks.

Setiyadi, Nugroho, J. 2003, Perilaku Konsumen, Konsep dan Implikasi untuk Strategi Penelitian Pemasaran, Prenada Media, Jakarta.

Sugiyono. (2010). Metode Penelitian Kuantitatif, Kualitatif dan R\&D. Bandung : Alfabeta.

Sugiyono. (2014). Metode Penelitian Manajemen. Bandung: Alfabeta.

Sugiyono.(2012). Metode Penelitian Pendidikan. Bandung: Alfabeta

Sutisna. (2001). Perilaku Konsumen dan Komunikasi Pemasaran. PT. Remaja Rosdakarya, Bandung.

Sutisna. (2001). Perilaku Konsumen dan Komunikasi Pemasaran. PT. Remaja Rosdakarya, Bandung.

Tjiptono, Fandy, 2002, Strategi Pemasaran, Andi Offset, Yogyakarta.

Wayan Adi Virawan 2013, Pengaruh Harga, Kualitas Produk Dan Citra Merek Terhadap Keputusan Pembelian (Studi Pada Mahasiswa Fakultas Ekonomi Universitas Negeri Yogyakarta Pengguna Helm Merek Ink). Jurnal Skripsi, Fakultas Ekonomi Universitas Negeri Yogyakarta.

Wirayanthy, N., \& Santoso, S. (2018). Pengaruh Harga, Citra Merek Dan Kualitas Terhadap Minat Beli Produk Private Label. JMD: Jurnal Riset Manajemen \& Bisnis Dewantara, 1(2), 87-96. 